\title{
ARAHAN PRODUK PARIWISATA BERBASIS MASYARAKAT LOKAL DI WILAYAH PERDESAAN
}

\author{
I Made Adikampana ${ }^{1}$, I Nyoman Sunarta ${ }^{2}$, I Made Kusuma Negara ${ }^{3}$ \\ adikampana@unud.ac.id \\ Program Studi S1 Destinasi Pariwisata, Fakultas Pariwisata, Universitas Udayana \\ ${ }^{2}$ nyoman_sunarta@unud.ac.id \\ Program Studi S1 Destinasi Pariwisata, Fakultas Pariwisata, Universitas Udayana \\ ${ }^{3}$ kusuma.negara@unud.ac.id \\ Program Studi S1 Industri Perjalanan Wisata, Fakultas Pariwisata, Universitas Udayana
}

\begin{abstract}
This paper addressed the referrals formulation of the development of community-based rural tourism products in Pinge Tourism Village, Tabanan Regency, Bali Province. The communitybased rural tourism products are acknowledged as a tourist pull factor in rural areas created by local communities based on the tourism resources that possess by communities themselves. Data required for the formulation were collected through observation, interview and study of literature, then analyzed descriptively to identify tourism resources and determine utilization such resources in a sustainable manner. Pinge Tourism Village has a various of tourism resources that can be developed as a local community-based rural tourism product. From the inside of the physical environment resources to the diversity of social and cultural heritage. In adaptation with the mapping of tourism resources, can be determined the themes of development of community-based rural tourism products. There are four themes that can be considered for the development of community-based rural tourism products in Pinge Tourism Village, specifically spiritual routine, agricultural routine, culinary routine, and communal routine. These four themes further form the basis for determining community-based rural tourism products or special interest tourism activities of traditional villages in Pinge Tourism Village. There are several referrals for the development of community-based rural tourism products that can be developed in Pinge Tourism Village such as spiritual tourism, agritourism, culinary tourism, and rural nightlife attraction.
\end{abstract}

\begin{abstract}
Abstrak: Tulisan ini ditujukan untuk menjelaskan perumusan arahan pengembangan produk pariwisata perdesaan berbasis masyarakat lokal di Desa Wisata Pinge, Kabupaten Tabanan, Provinsi Bali. Produk pariwisata perdesaan berbasis masyarakat lokal dipahami sebagai faktor penarik wisatawan di wilayah perdesaan yang diciptakan oleh masyarakat lokal berdasarkan keunikan sumber daya pariwisata yang dimiliki oleh masyarakat lokal itu sendiri. Data yang dibutuhkan untuk perumusan arahan tersebut, dikumpulkan melalui observasi, wawancara, serta studi literatur. Data yang terkumpul lalu dianalisis secara deskriptif untuk mengidentifikasi sumber daya pariwisata dan menentukan pemanfaatannya secara berkelanjutan. Desa Wisata Pinge mempunyai beragam sumber daya yang dapat dikembangkan sebagai produk pariwisata perdesaan berbasis masyarakat lokal. Mulai dari sumber daya lingkungan fisik sampai pada keragaman unsur sosial dan budaya. Dari penemukenalan sumber daya pariwisata tersebut, dapat ditentukan tema-tema pengembangan produk pariwisata perdesaan berbasis masyarakat lokal. Terdapat empat tema yang dapat dijadikan pertimbangan untuk pengembangan produk pariwisata perdesaan berbasis masyarakat lokal di Desa Wisata Pinge, yaitu rutinitas spiritual, rutinitas agrikultural, rutinitas boga, dan rutinitas komunal. Keempat tema tersebut selanjutnya menjadi dasar penentuan produk pariwisata perdesaan berbasis masyarakat lokal atau kegiatan wisata minat khusus kehidupan desa tradisional di Desa Wisata Pinge. Beberapa arahan pengembangan produk pariwisata perdesaan berbasis masyarakat lokal yang dapat dibangun di Desa Wisata Pinge diantaranya adalah pariwisata spiritual, pariwisata budaya pertanian, pariwisata kuliner, dan pariwisata malam.
\end{abstract}

Keywords: tourism product; resources; rural area; local community. 


\section{PENGANTAR}

Keterlibatan masyarakat lokal dalam pengembangan pariwisata di wilayah perdesaan merupakan syarat utama untuk memastikan keberlanjutan pembangunan pariwisata perdesaan (Bramwell, 2010; Byrd et al., 2009; Zou et al., 2014). Keterlibatan masyarakat lokal dalam pengembangan pariwisata tersebut, terkait dengan istilah partisipasi, pemberdayaan, ataupun perencanaan partisipatif. Selama ini, masyarakat lokal di wilayah perdesaan dipandang sebagai pemangku kepentingan (stakeholder) yang pasif dan reaktif (Daldeniz dan Hampton, 2013; Idziak et al., 2015). Melalui pengembangan pariwisata perdesaan, masyarakat lokal diyakini mampu menjadi pemangku kepentingan yang proaktif. Pariwisata perdesaan yang dikembangkan tidak hanya dapat dideskripsikan sebagai pariwisata berbasis masyarakat lokal melainkan juga sebagai pembangunan pariwisata berkelanjutan yang dikreasi oleh masyarakat lokal. Dalam konteks tersebut, masyarakat lokal secara kolektif dan kreatif mampu menciptakan produk dan pengalaman pariwisata perdesaan bermutu melalui partisipasi masyarakat lokal dalam proses perencanaan dan manajemen kepariwisataan (Idziak et al., 2015).

Namun penyediaan produk dan pengalaman pariwisata berkualitas merupakan permasalahan utama dalam pengembangan pariwisata perdesaan (Carson et al., 2014; Romeiro dan Costa, 2010). Permasalahan tersebut juga muncul dalam pengembangan Desa Wisata Pinge sebagai destinasi pariwisata perdesaan unggul di Provinsi Bali. Desa Wisata Pinge merupakan sebuah desa adat (desa pakraman) di Bali yang ditetapkan oleh pemerintah daerah sebagai desa wisata pada tahun 2004. Adanya penetapan tersebut tidak serta merta diikuti dengan pengembangan produk pariwisata, terutama oleh pemerintah daerah maupun masyarakat lokal. Akibatnya adalah keberadaan Desa Wisata Pinge sampai saat ini masih kurang mendapatkan perhatian berarti khususnya dari pasar atau wisatawan dan juga pelaku pariwisata lainnya.

Berdasarkan fenomena tersebut, tulisan ini ditujukan untuk menemukenali sumber daya pariwisata guna merumuskan arahan pengembangan produk pariwisata perdesaan berbasis masyarakat lokal di Desa Wisata
Pinge. Produk pariwisata perdesaan berbasis masyarakat lokal dipahami sebagai faktor penarik wisatawan yang diciptakan oleh masyarakat lokal di wilayah perdesaan berdasarkan sumber daya pariwisata atau keunikan yang dimiliki oleh masyarakat lokal itu sendiri. Reid, et al. (2009) juga menyebutkan bahwa produk pariwisata dapat diidentifikasi berdasarkan keunikan yang dimiliki masyarakat setempat dan adanya kesesuaian dengan pasar yang disasar.

\section{Produk Pariwisata}

Produk pariwisata dibutuhkan sebagai prasyarat untuk memberikan kepuasan bagi wisatawan yang selalu mengalami perubahan permintaan. Selain itu, pengembangan produk pariwisata semestinya mampu memberikan jaminan keuntungan jangka panjang bagi masyarakat lokal dan pelaku pariwisata lainnya. Idealnya, produk pariwisata dapat memenuhi tuntutan pasar yang dinamis, diproduksi dengan efektif dan efisien, dan didasarkan pada pemanfaatan secara bijak sumber daya di daerah tujuan pariwisata atau destinasi pariwisata.

Secara umum, konsep produk mengacu pada komoditas yang dihasilkan oleh suatu industri. Dengan demikian, produk pariwisata merupakan komoditas yang dihasilkan oleh industri pariwisata guna memfasilitasi pergerakan/perjalanan dan aktivitas wisata yang dilakukan oleh individu maupun kelompok di destinasi pariwisata (Smith, 1994). Kemudian masih dalam ulasannya, Smith menegaskan bahwa produk pariwisata dapat dijelaskan dari dua perspektif, yaitu sisi permintaan dan sisi penawaran.

Produk pariwisata berdasarkan perspektif permintaan merupakan segala sesuatu yang dapat ditawarkan kepada pasar, baik pasar aktual maupun pasar potensial (Boniface et al., 2012), dapat diakuisisi, digunakan, atau dikonsumsi untuk memuskan keinginan atau kebutuhan ketika mengisi waktu luang. Termasuk dalam hal ini adalah objek fisik, pelayanan, orang, aktivitas, tempat, organisasi, dan ide atau gagasan. Pemahaman tersebut memberikan gambaran bahwa produk pariwisata tidak hanya objek fisik, melainkan juga objek non-fisik, seperti aktifitas, interaksi, organisasi, dan gagasan. Kemudian produk pariwisata juga disebutkan sebagai suatu paket aktivitas, pelayanan, dan manfaat yang menghasilkan pengalaman wisata. Paket 
terdiri dari lima komponen, yaitu atraksi, fasilitas, aksesibilitas, citra, dan harga. Kelima komponen produk tersebut dan ditambah dengan komponen organisasi menurut Inskeep (1991) merupakan komponen pembangunan kepariwisataan. Selanjutnya dari perspektif penawaran, produk pariwisata didefinisikan sebagai jenis pariwisata yang dikembangkan di suatu destinasi pariwisata berdasarkan skala aktivitas dan layanan. Jenis pariwisata meliputi pariwisata konvensional dan pariwisata alternatif. Dalam penelitian ini, pariwisata berbasis masyarakat lokal termasuk dalam jenis pariwisata alternatif yang fokus kepada keterlibatan atau partisipasi masyarakat lokal dalam pengembangan produk pariwisata di suatu destinasi pariwisata perdesaan.

\section{Pariwisata Perdesaan}

Pariwisata perdesaan dapat dilihat sebagai pariwisata yang tumbuh di wilayah perdesaan. Namun pada dasarnya pariwisata perdesaan tidak hanya dapat dipahami berdasarkan aspek geografis semata, melainkan juga menjadi bagian tidak terpisahkan dengan lingkungan dan kehidupan masyarakat lokal (Lane, 1994; Roberts dan Hall, 2004). Untuk itu kemudian pariwisata perdesaan harus memenuhi beberapa kriteria, yakni :

1. Berlokasi di wilayah perdesaan

2. Menjalankan fungsi-fungsi perdesaan

3. Berskala kecil

4. Bersifat tradisional

5. Tumbuh perlahan dan seimbang

6. Dikelola oleh masyarakat lokal

Untuk memenuhi keriteria-kriteria tersebut, maka isu penting yang perlu mendapatkan perhatian adalah dampak pengembangan pariwisata terhadap wilayah perdesaan. Beberapa literatur menunjukkan bahwa dampak pariwisata terhadap wilayah perdesaan akan berbeda-beda tergantung dari jumlah dan jenis wisatawan yang berkunjung, pengorganisasian produk pariwisata, integrasi pariwisata dalam pengembangan masyarakat perdesaan, dan tahapan dalam siklus hidup destinasi pariwisata (Briedenham dan Wickens, 2004; Barke, 2004). Kajian-kajian tersebut juga menyatakan bahwa selain ketrampilan, aspek koordinasi dan kontrol masyarakat lokal akan sangat menentukan dampak pariwisata perdesaan. Sebagai contoh Barke (2004) menyebutkan kasus tentang kepemilikan usaha pariwisata perdesaan oleh individu atau pengusaha non-lokal telah menjadikan masyarakat lokal tidak mendapatkan keuntungan berarti dari pengembangan pariwisata perdesaan. Page dan Getz (1997) berdasarkan beberapa hasil penelitian tentang sikap masyarakat lokal terhadap pariwisata menyimpulkan bahwa masyarakat lokal yang mendapatkan manfaat dan mempunyai kontrol terhadap pengembangan pariwisata cenderung bersikap positif. Simpulan tersebut juga didukung oleh pernyataan World Tourism Organization (WTO, 1998) yang menyebutkan melalui partisipasi, masyarakat akan lebih mendapatkan manfaat pariwisata dalam bentuk pekerjaan dan pendapatan, menciptakan peluang berusaha serta keuntungan lainnya. Selanjutnya dengan mendapat berbagai manfaat tersebut, masyarakat akan menerima, mendukung, dan toleran terhadap pengembangan pariwisata.

Optimalisasi dampak positif pariwisata memerlukan pertimbangan matang dan pemenuhan terhadap prinsip-prinsip pembangunan berkelanjutan. Prinsip pembangunan berkelanjutan terkait erat dengan pengembangan pariwisata yang ramah lingkungan, layak secara ekonomi, dan dapat diterima secara sosial dan budaya masyarakat lokal. Mengikuti WTO (1998), pariwisata berkelanjutan harus menjamin tiga hal penting yaitu :

1. Memanfaatkan secara optimal (seimbang) sumber daya lingkungan fisik

2. Menghormati keaslian sosial budaya masyarakat lokal

3. Memastikan kelayakan dan manfaat sosial ekonomi (pekerjaan, pendapatan, layanan sosial, dan pengentasan kemiskinan) bagi para pengambil keputusan.

Pengembangan pariwisata berkelanjutan membutuhkan keterlibatan dari segenap pengambil keputusan yang terkait serta kepemimpinan yang kuat untuk memastikan tumbuhnya ruang-ruang berpartisipasi terutama bagi masyarakat lokal. Pariwisata berkelanjutan juga harus mampu memberikan kepuasan dan kesadaran bagi wisatawan tentang isu-isu pariwisata yang berkelanjutan.

\section{METODE}

Artikel tentang produk pariwisata berbasis masyarakat lokal di wilayah perdesaan menggunakan pendekatan kualitatif. Pendekatan ini merupakan cara untuk 
mengungkap situasi dan fenomena secara lebih mendalam berdasarkan pemahaman dan pengalaman masyarakat lokal. Teknik pengumpulan data melalui observasi, wawancara, serta studi literatur. Wawancara dilakukan terhadap informan terpilih (purposif) karena pengetahuan dan ketokohannya sehingga mampu memberikan informasi yang komprehensif. Keseluruhan informan terdiri dari unsur pemimpin desa adat, kelompok sadar wisata (pokdarwis), badan pengelola desa wisata, subak, dan kelompok wanita. Informasi yang digali terkait dengan perspektif masing-masing informan tentang keberadaan sumber daya pariwisata dan pemanfaatannya secara berkelanjutan. Informasi yang terkumpul selanjutnya ditafsirkan dan disajikan sesuai dengan sebenarnya secara deskriptif. Proses analisis deskriptif sepenuhnya dikaji dan dikembangkan berdasarkan pengalaman di lapangan. Pada awalnya, data yang diperoleh dari berbagai sumber dianalisis bersaman dengan proses pengambilan data tersebut dan kemudian dilanjutkan dengan kategorisasi data. Dari proses ini diperoleh spesifikasi data yang akan diinterpretasi dan dihubungkan satu dengan yang lainnya untuk memperoleh konteks tertentu. Setelah diperoleh konteks hubungan, lalu dilakukan penarikan kesimpulan yang relevan mengenai ragam sumber daya pariwisata perdesaan, tema pengembangan, dan arahan pengembangan produk pariwisata perdesaan berbasis masyarakat lokal.

\section{PEMBAHASAN}

\section{Perkembangan Desa Wisata Pinge}

Perkembangan Desa Wisata Pinge dimulai sejak penetapannya sebagai desa wisata berdasarkan Surat Keputusan Bupati Tabanan No. 337 Tahun 2004. Namun adanya penetapan tersebut, tidak diimbangi dengan rangkaian strategi dan program pengembangan baik oleh Pemerintah Kabupaten Tabanan maupun masyarakat lokal. Hal ini menyebabkan Desa Wisata Pinge sampai saat ini belum mendapatkan tanggapan berarti dari wisatawan dan juga para pelaku industri pariwisata. Keadaan ini kemudian relatif berubah, ketika pada tahun 2011 muncul inisiatif dari beberapa warga masyarakat lokal untuk mengembangkan produk desa wisata. Masyarakat lokal mulai mengadakan program penataan desa, memberdayakan kaum perempuan melalui Kelompok Merta Dewi, menentukan jalur-jalur jelajah desa (trekking), dan memfungsikan beberapa tempat tinggal masyarakat lokal sebagai homestay. Selanjutnya pada tahun 2012 dibentuk Badan Pengelola Desa Wisata Pinge sesuai dengan keputusan Desa Pakraman Pinge No. 01 Tahun 2012. Badan ini diberikan mandat untuk merencanakan dan mengembangkan Desa Wisata Pinge.

Implementasi program pengembangan tersebut telah mampu menarik kunjungan wisatawan terutama yang berasal dari Prancis dan Jerman. Berdasarkan kunjungan tersebut, dikatakan bahwa hampir $25 \%$ merupakan pengunjung yang menginap di homestay yang dikembangkan oleh masyarakat lokal, sedangkan sisanya dapat diklasifikasikan ke dalam pengunjung harian. Pergerakan kunjungan wisatawan ke Desa Wisata Pinge ini membawa optimisme masyarakat lokal untuk semakin fokus mengembangkan pariwisata di wilayahnya. Hal ini diwujudkan dengan kegiatan launching dan familiarization tour Desa Wisata Pinge pada tanggal 30 Januari 2013, terhadap beberapa biro perjalanan wisata, pemerintah provinsi dan kabupaten, akademisi, dan pihak-pihak lain yang terkait. Berdasarkan kronologis perkembangan pariwisata perdesaan di Desa Wisata Pinge, dapat dikatakan bahwa telah terjadi kevakuman pengembangan pariwisata selama tujuh tahun, yaitu antara tahun 2004 sampai dengan 2011. Kekosongan yang ada, relatif mulai terisi dengan beberapa program pengembangan yang bersumber dari inisiatif sejumlah warga masyarakat lokal.

Partisipasi masyarakat lokal dalam pengembangan Desa Wisata Pinge termasuk ke dalam jenis partisipasi koersif. Partisipasi jenis ini jelas teramati dalam perkembangannya, karena menurut Tosun (2006) partisipasi koersif mempunyai ciri-ciri tertentu, yaitu program pengembangan bersifat sentralistis, masyarakat hanya terlibat dalam implementasi program, paternalistik, dan masyarakat berposisi pasif serta manipulatif. Akibat yang timbul dari partisipasi berjenis koersif adalah masih minimnya pembagian manfaat pariwisata untuk masyarakat lokal. Disamping itu, perkembangan Desa Wisata Pinge jika dikaitkan dengan siklus hidup destinasi pariwisata, menunjukkan indikasi berada dalam tahapan embriotik. Destinasi pada tahap embriotik atau eksplorasi menurut 
Butler (1980) memiliki karakteristik jumlah pengunjung sedikit khususnya pengunjung yang menginap, menggunakan fasilitas masyarakat lokal untuk pariwisata, dan tidak ada perubahan lingkungan, sosial, budaya, dan ekonomi masyarakat. Juga pada tahap embriotik terdapat penerimaan, dukungan, dan toleransi masyarakat yang tinggi terhadap pariwisata. Implikasi dari tahapan embriotik ini adalah manfaat pariwisata perdesaan yang dihasilkan relatif terbatas. Selain terbatas, berbagai manfaat pariwisata yang dibangkitkan oleh Desa Wisata Pinge belum sepenuhnya dinikmati oleh mayoritas masyarakat lokal.

Untuk meningkatkan kontribusi atau manfaat pariwisata bagi masyarakat lokal secara kolektif, dibutuhkan suatu strategi pengembangan produk pariwisata perdesaan. Produk pariwisata yang dibangun berbasis sumber daya yang dimiliki masyarakat lokal. Pemanfaatan sumber daya tersebut dimaksudkan agar masyarakat lokal secara langsung terlibat dalam setiap proses perencanaan, baik dalam pengambilan keputusan maupun untuk menentukan pembagian manfaat pariwisata secara adil.

\section{Sumber Daya Pariwisata}

Inskeep (1991) menyatakan bahwa prinsip dalam memahami perencanaan pariwisata adalah pengetahuan dan interelasi berbagai komponen pembangunan kepariwisataan. Salah satu komponen pembangunan kepariwisataan adalah ketersediaan atraksi dan aktivitas pariwisata. Atraksi dan aktivitas pariwisata dipahami sebagai keseluruhan karakteristik alam, budaya, dan ciri unik lainnya beserta aktivitas di dalamnya, yang mampu menarik kunjungan. Sesuai dengan pernyataan Inskeep tersebut maka sumber daya pariwisata di Desa Wisata Pinge dapat dikelompokkan menjadi dua.

\section{Sumber daya lingkungan fisik}

Secara administratif Desa Wisata Pinge terletak di Kecamatan Marga, Kabupaten Tabanan, Provinsi Bali. Desa wisata ini memiliki bentuk wilayah yang unik yaitu linier memanjang mengikuti ruas jalan desa dengan luas wilayah 240,75 Ha. Sebagian besar peruntukan lahannya dimanfaatkan sebagai lahan persawahan dan tegalan, sedangkan sisanya untuk tempat tinggal dan fasilitas komunal. Selain keunikan morfologi desa,
Desa Wisata Pinge juga diapit oleh dua aliran sungai. Keberadaan sungai ini mampu memenuhi kebutuhan air masyarakat lokal.

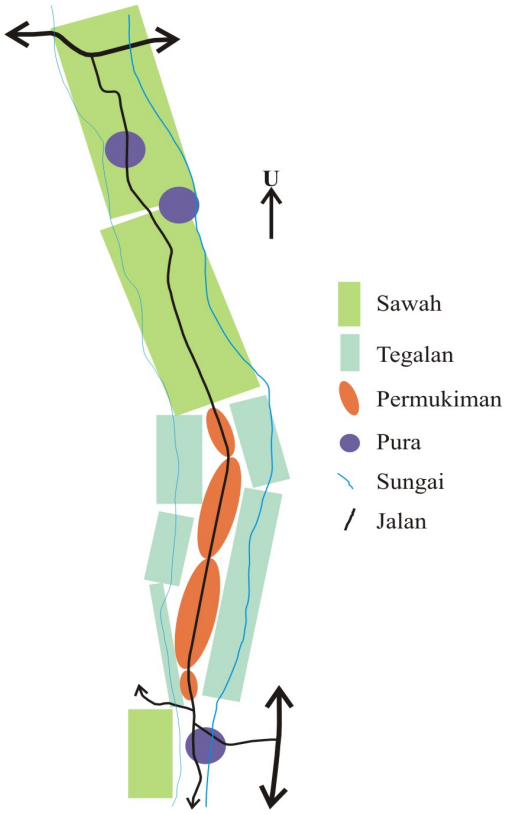

Gambar 1. Penggunaan Lahan di Desa Wisata Pinge

Luas areal persawahan di Desa Wisata Pinge berjumlah $105 \mathrm{Ha}$ atau sekitar 44\% dari total luasan desa. Selain padi yang selalu ditanam setiap tahunnya, masyarakat lokal juga membudidayakan tanaman holtikultura yaitu sayur mayur dan bunga yang digunakan untuk keperluan upacara keagamaan. Beberapa jenis sayur-sayuran dan bunga yang ditanam berupa Kol, Buncis, Tomat, Cabe, Asparagus, Mentimun, Ubi, Bunga Gemitir (Marigold) dan Bunga Pacar Air (Impatiens balsamina L.). Hasil dari persawahan ini, sebagian besar untuk memenuhi kebutuhan sehari-hari masyarakat lokal sendiri (subsisten). Selain dari hasil sawah, masyarakat lokal juga memenuhi kebutuhan dan keperluannya dari hasil tegalan dan pekarangan. Ruang yang dimanfaatkan untuk tegalan dan pekarangan biasanya berada di area belakang atau di sekitar tempat tinggal. Tegalan dan pekarangan di Desa Wisata Pinge mayoritas ditanami buah-buahan, seperti Pisang, Pepaya, Jeruk, Sawo, Jambu, Manggis, Duku, Nangka, Durian, dan lain-lain. Selain buah-buahan, masyarakat lokal juga menanam beberapa tanaman keras; Kelapa, Coklat, Cengkeh, Kopi, tanaman kayu; Jati, Mahoni, Albesia, tanaman obat-obatan; Sirih, Kayu Manis, Dadap, Sembung, Kunyit Putih, Liligundi, 
Kembang Bintang, Binahong, Mengkudu, Semanggi, Kecombrang, dan tanaman lanskap; Andong, Parigata, Kamboja. Selain tanamantanaman tersebut, tegalan dan pekarangan juga difungsikan untuk memelihara ternak, diantaranya Babi, Sapi, Ayam, dan burung, serta ikan. Di Desa Wisata Pinge juga terdapat banyak hewan non-budidaya seperti Belut dan Keong Sawah yang juga dapat dimanfaatkan terutama sebagai bahan makanan.

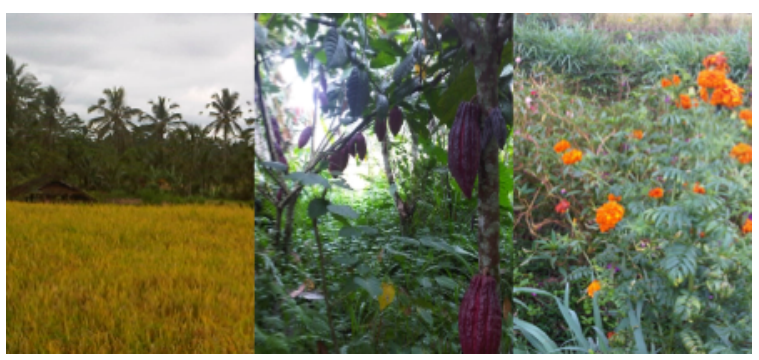

Gambar 2. Persawahan, Tegalan, dan Pekarangan

\section{Sumber daya sosial budaya}

Sumber daya sosial budaya dalam pariwisata adalah sistem sosial, sistem budaya, dan sistem karya yang dihasilkan dan dilaksanakan dalam bentuk aktivitas keseharian masyarakat (Feighery, 2008). Berdasarkan batasan tersebut, sumber daya sosial budaya di Desa Wisata Pinge yang dapat dikreasikan menjadi produk desa wisata adalah pura dan tinggalan arkeologis, pola desa, tata ruang tempat tinggal, kesenian, dan banjar.

a. Pura dan tinggalan arkeologis

Desa Wisata Pinge berdasarkan sejarahnya, merupakan salah satu desa tua di Bali. Hal tersebut terbukti dengan adanya bendabenda tinggalan arkeologis yang dapat diamati pada beberapa pura terutama di Pura Natar Jemeng. Berdasarkan temuan tinggalan tersebut, Pemerintah Provinsi Bali kemudian menetapkan Pura Natar Jemeng sebagai salah satu cagar budaya. Selain Pura Natar Jemeng, di Desa Wisata Pinge juga terdapat 14 pura lain yang letaknya horizontal dengan tegalan dan pekarangan masyarakat lokal. Beberapa pura yang berada di Desa Wisata Pinge dapat disebutkan sebagai berikut : Pura Tri Khayangan, Pura Melanting Desa, Pura Beji, Tugu Margi Agung, Tugu Tegal Pangsaran, Tugu Tegal Suci, Tugu Niti Ugal Ugil, Pura Gunung Sari, Pura Panglumbungan, Pura Bedugul Pacung,
Pura Gunung Lingga, Pura Taman Bagendra, Pura Natar Panti, dan Pelinggih Mangku Wikan. Keberadaan berbagai pura di Desa Wisata Pinge merupakan pengikat bagi masyarakat lokal dan menghasilkan aktivitas keagamaan atau ritual masyarakat yang sangat beragam. Keragaman dan intensitas ritual masyarakat lokal ini merupakan potensi yang tidak dapat dijumpai di tempat lainnya.

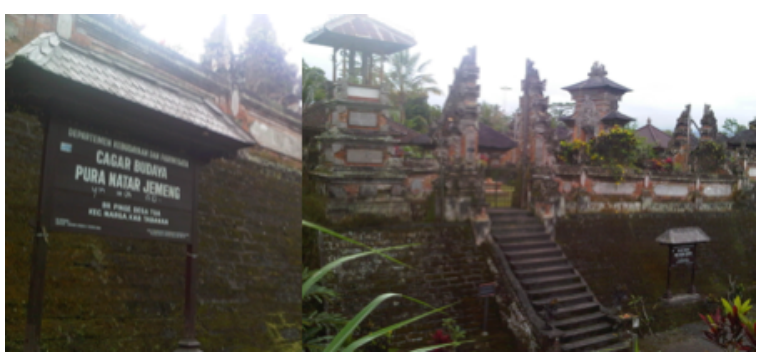

Gambar 3. Cagar Budaya Pura Natar Jemeng

b. Pola desa

Morfologi Desa Wisata Pinge sangatlah unik. Desa ini membujur Utara Selatan dan dibelah oleh sebuah rurung atau jalan desa. Jalan desa ini menjadi orientasi tempat tinggal (karang) dan tempat bekerja bagi masyarakat lokal.

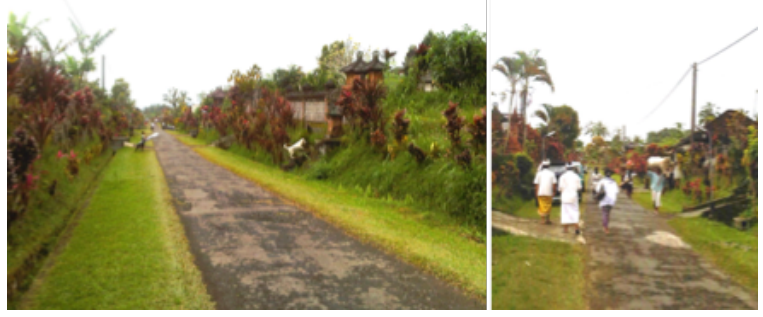

Gambar 4. Morfologi Desa dan Aktivitas Masyarakat

c. Tata ruang tempat tinggal

Dalam satu karang atau tempat tinggal didiami oleh beberapa kepala keluarga (KK) yang mempunyai hubungan keluarga. Setiap karang memiliki sejumlah bangunan dengan fungsi yang berbeda. Sanggah Pemerajan merupakan tempat suci terletak di sebelah Utara atau Timur, Bale Dangin sebagai tempat upakara dan tempat tinggal, Paon atau dapur untuk memproses 
makanan dan minuman, serta keberadaan Lumbung sebagai tempat penyimpanan hasil-hasil pertanian.

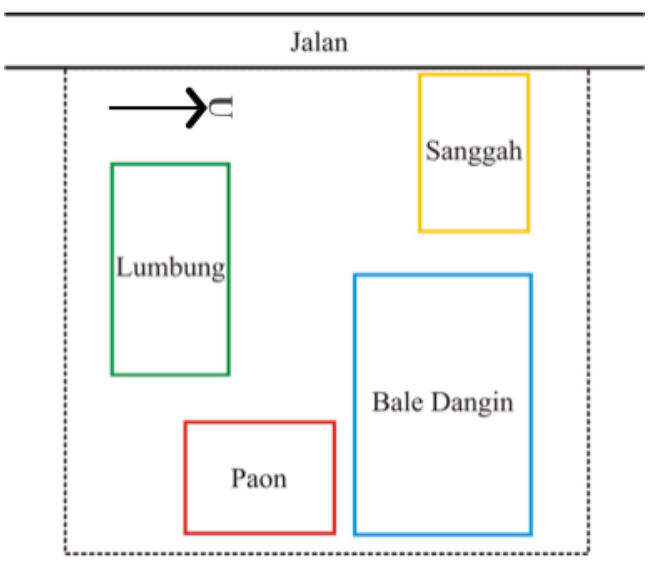

Gambar 5. Tata Ruang Tempat Tinggal

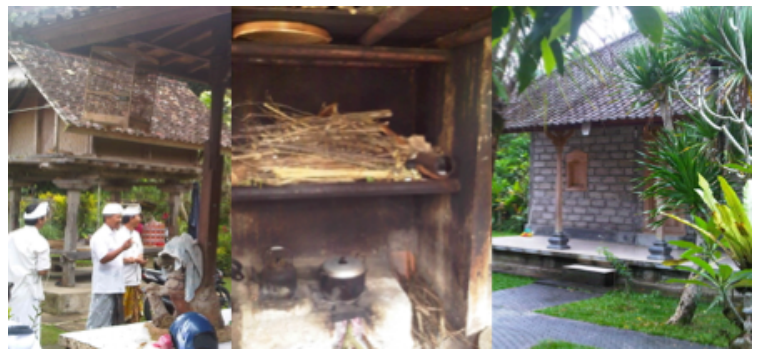

Gambar 6. Lumbung, Dapur, dan Bale Dangin

d. Kesenian

Kesenian yang berkembang di Desa Wisata Pinge berupa seni tari dan seni karawitan. Khusus untuk seni tari, di Desa Wisata Pinge terdapat tarian khas yang dikenal dengan Tari Leko, Tari Wali Pendet dan Bumbung Gebiog. Jenis dan bentuk Tarian Leko menyerupai tarian joged dan Legong Keraton serta sangat berkaitan dengan keberadaan Pura Natar Jemeng. Sedangkan seni karawitan yang berkembang berupa Gong, Beleganjur, Rindik, Leko, Tabuh Gebiog, dan pesantian.

e. Banjar

Banjar merupakan suatu tatanan organisasi yang terdiri dari tempat, kegiatan, orang, peraturan, sanksi serta adanya pimpinan yang mengatur seluruh kegiatan untuk mencapai tujuan tertentu. Fungsi banjar adalah sebagai tempat perkumpulan masyarakat dalam melakukan kegiatankegiatan yang bersifat kebersamaan dan sebagai tempat komunikasi dalam rangka membagi berbagai macam informasi.

\section{Tema Produk Pariwisata}

Berdasarkan pemetaan sumber daya pariwisata, dapat disebutkan bahwa Desa Wisata Pinge memiliki berapa keunikan yang menjadi basis pengembangan produk desa wisata yang dikreasi oleh masyarakat lokal. Keunikan tersebut merupakan paduan antara lingkungan fisik dan juga aktivitas keseharian atau rutinitas sosial, budaya, maupun ekonomi masyarakat lokal :

a. Desa yang penuh dengan ragam ritual karena keberadaan pura yang cukup banyak jumlahnya dan setiap karang atau tempat tinggal yang biasanya dihuni oleh lebih dari satu KK juga terdapat sanggah pemerajan. Ini menjadikan Desa Wisata Pinge kaya akan aktivitas keagamaan. Keunikan ini disebut dengan rutinitas spiritual.

b. Penggunaan lahan didominasi oleh persawahan dan tegalan. Sekitar $92 \%$ dari keseluruhan luas wilayah Desa Wisata Pinge dimanfaatkan untuk sawah dan tegalan. Mayoritas mata pencaharian masyarakat lokal adalah sebagai petani. Kondisi demikian memunculkan tema rutinitas agrikultural.

c. Makanan dan minuman yang dikonsumsi oleh masyarakat selama ini diolah dari bahan-bahan yang dihasilkan sendiri. Proses mengambil bahan-bahan makanan, memasak, menyajikan, sampai menikmati makanan merupakan bagian dari keseharian masyarakat lokal, terutama kaum perempuan di Desa Wisata Pinge. Keseharian masyarakat lokal tersebut diistilahkan dengan rutinitas boga.

d. Banjar sebagai media bertemu dan berkumpul masyarakat lokal dalam rangka membagi berbagai informasi maupun berkesenian. Berbagai rutinitas komunal tersebut terkonsentrasi di bale banjar.

Keunikan yang teridentifikasi tersebut, tercermin juga dalam skala mikro yaitu pola keruangan tempat tinggal masyarakat lokal. Setiap tempat tinggal atau karang masyarakat lokal umumnya juga memiliki bangunan dengan fungsi berbeda dan mencerminkan keunikan Desa Wisata Pinge dalam skala makro.

a. Sanggah pemerajan menunjukkan adanya rutinitas spiritual.

b. Bangunan lumbung berhubungan dengan aktivitas keseharian masyarakat berbudaya agraris (rutinitas agrikultural) baik di lahan persawahan, tegalan maupun pekarangan. 
c. Paon atau dapur, merupakan tempat mengolah berbagai bahan makanan dan minuman hasil budidaya di lahan persawahan, tegalan, dan pekarangan menjadi berbagai jenis makanan dan minuman khas Desa Wisata Pinge. Keberadaan paon atau dapur memperlihatkan rutinitas boga.

d. Bale Dangin sebagai tempat berkumpul dan berinteraksi antara sesama anggota keluarga. Di bangunan inilah tercermin rutinitas komunal.

\section{Produk Pariwisata Perdesaan}

Produk pariwisata perdesaan adalah pengembangan nilai-nilai yang terkandung dalam objek fisik, sosial, dan budaya otentik dalam wilayah perdesaan untuk memberikan pengalaman yang baru bagi wisatawan (Idziak et al., 2015). Wisatawan yang mengunjungi wilayah perdesaan termotivasi untuk mengalami langsung kehidupan atau melakukan kegiatan keseharian masyarakat perdesaan (George et al., 2009; Roberts dan Hall, 2001). Untuk itu, dalam penentuan produk pariwisata perdesaan di Desa Wisata Pinge didasarkan atas nilai-nilai lingkungan fisik, sosial, dan budaya yang tampak pada kegiatan keseharian atau rutinitas masyarakat di Desa Wisata Pinge. Dengan mempertimbangkan rumusan tema dalam pembahasan sebelumnya, maka beberapa produk Desa Wisata Pinge yang dapat ditawarkan kepada pasar atau wisatawan yang disasar berupa :

a. Pariwisata spiritual

Di Desa Wisata Pinge sedikitnya terdapat 15 pura dan belum termasuk sanggah pemerajan yang berada di setiap tempat tinggal masyarakat lokal. Dengan demikian dapat dikatakan Desa Wisata Pinge sangat kaya akan berbagai aktivitas ritual atau upacara keagamaan. Wisatawan yang memilih atraksi ini akan mendapatkan pengalaman dan pembelajaran tentang proses ritual dan spiritual khususnya dalam upacara Agama Hindu. Berbagai pengalaman dan pembelajaran didapatkan mulai dari tahapan persiapan, pembuatan sarana prasarana upakara, sampai pada pelaksanaan upacara keagamaan.

b. Pariwisata budaya pertanian

Atraksi wisata budaya pertanian mengadopsi rutinitas dalam proses pertanian di Desa Wisata Pinge, baik di lahan persawahan, tegalan, maupun di pekarangan. Wisatawan dapat mengikuti seluruh proses tersebut untuk mendapatkan pengalaman dan pembelajaran budaya pertanian (agrikultur) berdasarkan sistem subak yang telah menjadi warisan budaya dunia.

c. Pariwisata kuliner

Pengalaman dan pembelajaran mengolah bahan makanan dan minuman dan menikmati kuliner yang segar dan sehat hanya ditemukan di Desa Wisata Pinge. Jenis makanan dan minuman di Desa Wisata Pinge sangat khas, karena sebagian besar bahan bakunya bersumber dari hasil budidaya sendiri. Wisatawan akan dapat mengambil bahan-bahan makanan dan minuman dari lahan persawahan, tegalan maupun pekarangan dan selanjutnya dapat diolah di paon atau dapur yang dimiliki masyarakat lokal. Atraksi yang ditawarkan sangat interaktif dan mampu memberdayakan masyarakat lokal terutama kelompok perempuan. Dalam atraksi ini terdapat interaksi intensif antara wisatawan dengan masyarakat lokal dalam persiapan, pengolahan, penyajian, dan menikmati makanan dan minuman khas Desa Wisata Pinge.

d. Pariwisata malam

Produk ini dapat dikatakan sebagai atraksi wisata malam, yang dapat "memaksa" pengunjung untuk menginap di Desa Wisata Pinge. Aktivitas yang dilakukan adalah berkomunikasi dengan masyarakat lokal setelah masyarakat tersebut seharian bekerja di sawah dan tegalan, menikmati kesenian yang ditampilkan, maupun belajar berkesenian dengan menari ataupun memainkan salah satu jenis alat musik tradisional yang bertempat di bale banjar. Diharapkan dengan adanya pengunjung yang menginap akan dapat memberikan manfaat yang lebih berarti utamanya bagi masyarakat lokal.

\section{SIMPULAN}

Desa Wisata Pinge mempunyai beragam sumber daya yang dapat dikembangkan sebagai produk pariwisata perdesaan berbasis masyarakat lokal. Mulai dari sumber daya lingkungan fisik sampai pada keragaman unsur sosial dan budaya. Dari pemetaan sumber daya pariwisata tersebut, dapat ditentukan tematema pengembangan produk pariwisata 
perdesaan berbasis masyarakat lokal. Terdapat

empat tema yang dapat dijadikan pertimbangan untuk pengembangan produk pariwisata perdesaan berbasis masyarakat lokal di Desa Wisata Pinge, yaitu rutinitas spiritual, rutinitas agrikultural, rutinitas boga, dan rutinitas komunal. Keempat tema tersebut selanjutnya menjadi dasar penentuan produk pariwisata perdesaan atau kegiatan wisata minat khusus desa tradisional Bali di Desa Wisata Pinge. Beberapa produk pariwisata perdesaan berbasis masyarakat lokal yang dapat dibangun di Desa Wisata Pinge diantaranya adalah pariwisata spiritual, pariwisata budaya pertanian, pariwisata kuliner, dan pariwisata malam. Produk pariwisata yang digagas ini akan dapat meningkatkan partisipasi masyarakat lokal dalam pengembangan pariwisata perdesaan dan mampu memberikan pengalaman serta pembelajaran tentang warisan tinggalan dan tradisi luhur bagi wisatawan.

Namun dalam pengembangan produk pariwisata perdesaan tersebut akan menghadapi tantangan, terutama adanya dominasi oleh sejumlah warga masyarakat yang menginisiasi pengembangan desa wisata pasca kevakuman selama tujuh tahun. Kondisi ini dapat menciptakan ketergantungan terhadap sejumlah warga tersebut dalam pengambilan keputusan perencanaan dan pengelolaan serta makin menguatkan sikap apatis masyarakat lokal terhadap pengembangan produk Desa Wisata Pinge. 


\section{Kepustakaan}

Barke, Michael. 2004. Rural Tourism In Spain, International Journal of Tourism Research. 6: 137-149.

Boniface, B., Cooper, C., and Cooper, R. 2012. Worldwide Destinations; the geography of travel and tourism. London: Routledge.

Bramwell, B. 2010. Participative Planning and Governance for Sustainable Tourism. Tourism Recreation Research. 35: 239-249.

Briedenhann, J. and Wickens, E. 2004. Rural Tourism-Meeting the Challenges of the New South Africa. International Journal of Tourism Research. 6: 189-203.

Butler, Richard W. 1980. The concept of a tourist area cycle of evolution: implications for management of resources. The Canadian Geographer/Le Géographe canadien. 24: 5-12.

Byrd, Erick T., Bosley, Holly E., and Dronberger, Meghan G. 2009. Comparisons of stakeholder perceptions of tourism impacts in rural eastern North Carolina. Tourism Management. 30: 693-703.

Carson, D. A., Carson, D. B., and Hodge, H. 2014. Understanding local innovation systems in peripheral tourism destinations. Tourism Geographies. 16: 457-473.

Daldeniz, B. and Hampton, Mark P. 2013. Dive Tourism and Local Communities: Active Participation or Subject to Impacts? Case Studies from Malaysia. International Journal of Tourism Research. 15: 507-520.

Feighery, William G. 2008. "Heritage Tourism in Xi'an: Constructing the Past in Contested Space". Dalam Janet Cochrane (ed). Asian Tourism: Growth and Change. UK: Elsevier.

George, E. Wanda, Mair, H., and Reid, Donald G. 2009. Rural Tourism Development: Localism and Cultural Change. UK: Channel View Publications.

Idziak, W., Majewski, J., and Zmyślony, P. 2015. Community participation in sustainable rural tourism experience creation: a longterm appraisal and lessons from a thematic villages project in Poland. Journal of Sustainable Tourism. 23:1341-1362.
Inskeep, E. 1991. Tourism Planning; An Integrated and Sustainable Development Approach. Canada: John Wiley \& Sons.

Lane, B. 1994. What is rural tourism?. Journal of Sustainable Tourism. 2: 7-21

Page, S. J. \& Getz, D. (Eds.), 1997, The business of rural tourism: international perspectives. London: International Thomson Business Press.

Reid, D. G., George, E. W., and Mair, H. 2009. Rural Tourism Development; Localism and Cultural Change. UK: Channel View Publications.

Roberts, L. and Hall, D. 2001. Rural Tourism and Recreation; Principles to Practice, UK: CABI Publishing.

Roberts, L. and Hall, D. 2004. Consuming the countryside: Marketing for rural tourism. Journal of Vacating Marketing. 10: 253-263.

Romeiro, P., and Costa, C. 2010 The potential of management networks in the innovation and competitiveness of rural tourism: a case study on the Valle del Jerte (Spain). Current Issues in Tourism. 13: 75-91.

Smith, S. L. J. 1994. The Tourism Product. Annals of Tourism Research. 21: 582-595.

Tosun, Cevat. 2006. Expected nature of community participation in tourism development. Tourism Management. 27: 493-504.

WTO. 1998. Guide for Local Authorities on Developing Sustainable Tourism. World Tourism Organization.

Zou, T., Huang, S., and Ding, P. 2014. Toward A Community-driven Development Model of Rural Tourism: The Chinese Experience. International Journal of Tourism Research. 16: 261-271 